\title{
RETROSPECTIVE SEROLOGICAL EVIDENCE OF HIGH EXPOSURE OF GLOBALLY RELEVANT ZOONOTIC PARASITE TOXOPLASMA GONDII IN THE LATVIAN POPULATION
}

\author{
Gunita Deksne ${ }^{1,2, \#}$, Vịa Veisa ${ }^{3}$, Dace Rezeberga ${ }^{3}$, Ludmila Vīksna ${ }^{4}$, \\ and Angelika Krūmina ${ }^{1,4,5}$

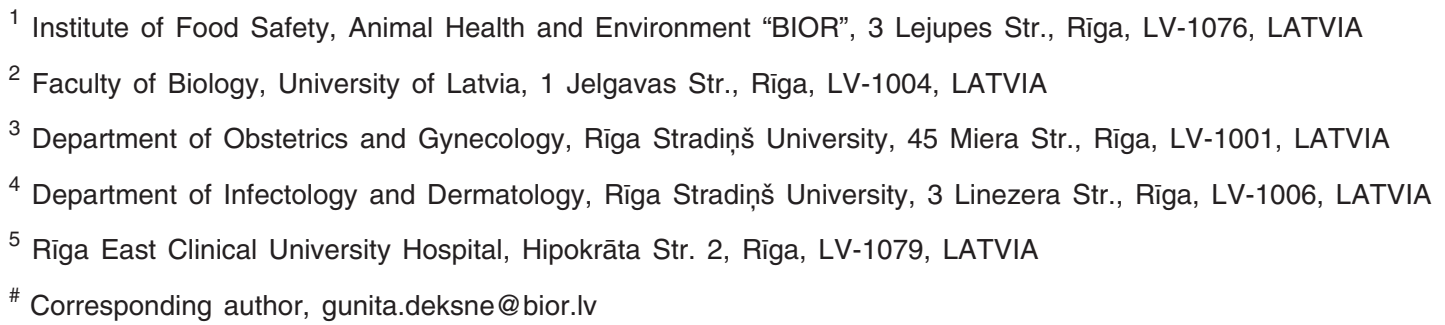

Contributed by Ludmila Vikksna

\begin{abstract}
Toxoplasmosis is an important infection caused by the single-celled parasite Toxoplasma gondii, which is a zoonotic parasite causing widespread human and animal diseases, mostly involving the central nervous system. Humans can acquire toxoplasmosis by ingestion of raw or undercooked meat containing T. gondii tissue cysts, ingestion of oocysts shed by infected felids via contaminated food or water, and by vertical transmission to the fetus through the placenta from the mother during pregnancy. The aim of the present study was to determine the seroprevalence of specific anti-T. gondii IgG and IgM antibodies using a large set of clinical diagnostic laboratory data obtained over a 14-year period. In total, 25069 unique patients were included in the present study. The overall specific anti-T. gondii IgG prevalence were $36.3 \%$, which was significantly $(\mathrm{p}<$ $0.01)$ higher than IgM prevalence (2.4\%). Mean age for IgG antibody-positive patients was $33.7 \pm$ 12.2 years. A significant positive correlation $(r=0.99 ; p<0.01)$ was observed between age group and anti-T. gondii IgG antibody prevalence, which ranged from $4.2 \%$ to $66.7 \%$. The most prevalent (69.9\%; 95\% Cl 69.2-70.7) comorbidities of patients tested for presence of anti-T. gondii IgG and IgM antibodies were classified as factors affecting health status which includes also monitoring of normal pregnancy.
\end{abstract}

Key words: toxoplasmosis, large scale, seroprevalence, age, comorbidity, pregnancy.

\section{INTRODUCTION}

Infection by the Apicomplexan parasite, Toxoplasma gondii causes toxoplasmosis. The parasite infects almost all warm-blooded animals. Serological evidence indicates that it is one of the most common infection of humans throughout the world (Dubey, 2010). The disease is transmitted mainly by ingestion of an infective stage of the parasite, organ transplantation, blood transfusion, and transplacental transmission, which is very common (Tenter et al., 2000). Most infected persons lack clinical manifestation of their infection and will never develop any symptoms. However, disease severity is highly variable. Severe eye disease resulting in loss of sight is not uncommon, and immunocompromised patients may present with serious infections of the central nervous system. Toxoplasmosis in acquired immune deficiency syndrome (AIDS) patients and other immunocompromised patients may be life threatening. Disease in these individuals can be due to recently acquired infection or more commonly due to reactivation of a latent infection. Toxoplasmosis is one of the opportunistic infections that AIDS patients develop (Sonar and Brahmbhatt, 2010). Toxoplasmosis ranks high on the list of diseases that lead to death in patients with AIDS; approximately 10\% of AIDS 
patients in the USA and up to $30 \%$ in Europe are estimated to have died from toxoplasmosis (Luft and Remington, 1992). Congenital infection occurs only when a woman becomes infected during pregnancy. While the mother rarely has symptoms of infection, she does have a temporary parasitemia. Focal lesions develop in the placenta and the foetus may become infected. At first a generalised infection appears in the foetus. Later, the infection is cleared from the visceral tissues and may localise in the central nervous system. A wide spectrum of clinical diseases occurs in congenitally infected children. Mild disease may consist of slightly diminished vision, whereas severely diseased children may have the full spectrum of symptoms: retino-choroiditis, hydrocephalus, convulsions and intracerebral calcification. Of these, hydrocephalus is the least common, but most dramatic, lesion of toxoplasmosis. The most common sequel of congenital toxoplasmosis is ocular disease (Tenter et al., 2000; Berger et al., 2009; Dubey, 2010).

To our knowledge, there are no accurate, empirical data that have been used to estimate incidence of toxoplasmosis in Latvia. Toxoplasma gondii was recently ranked $2^{\text {nd }}$ and $4^{\text {th }}$ among zoonotic parasites evaluated for their relevance as foodborne pathogens in Europe and globally, respectively (Anonymous, 2014; Bouwknegt et al., 2018). Estimates of infection prevalence are limited in scope. According to the Latvian Centre of Disease and Control, two to 16 acute toxoplasmosis cases per year were reported from 2002 to 2014. Starting from 2015 only congenital toxoplasmosis is reported and until August, 2018 zero cases were reported (Anonymous, 2018a). In 2014, 42 confirmed congenital toxoplasmosis cases were reported by 20 EU/EEA countries. The majority of cases in 2014 were reported from Poland (48\%) and the United Kingdom (26\%) (Anonymous, 2014).

In its acute infection form, toxoplasma spreads through all organs, and the parasite clears from the body in less than one week due to innate immunity and the rise of specific acquired immunity, including humoral immunity. Specific anti-T. gondii IgM antibodies are the first antibodies to appear, usually one week after the infection (RobertGangneux and Darde, 2012). Specific anti-T. gondii IgG antibodies appear after two weeks of infection and peaks at three months. The level then remains at a plateau for six months and after one year starts to slowly decrease to lower levels until the end of infected subject's life due to the persistence of latent cysts in immune privileged organs (Bessieres et al., 1992). Because of this, for seroprevalence studies the prevalence of specific anti-T. gondii IgG antibodies is estimated. Seroprevalence estimates for human populations vary greatly among different countries, among different geographical areas within one country, and among different ethnic groups living in the same area. The global prevalence of toxoplasmosis is about $30 \%$ of the world population. However, the distribution of human exposure to the parasite varies from 0 to $100 \%$ (Tenter et al., 2000; Dubey, 2010). Comparison of seroprevalence data of infections with $T$. gondii requires considering that the different serological methods used to obtain these data are not standardized (Tenter et al., 2000). For example, in Germany seroprevalence ranges from $20 \%$ (95\% CI 17-23\%) in the $18-29$ age group to $77 \%$ (95\% CI $73-81 \%$ ) in the $70-79$ age group (Wilking et al., 2016). The prevalence of toxoplasma infection in pregnant women ranges from $10 \%$ in the United Kingdom and Norway to around 55\% in France and Greece (Cook et al., 2000). However, the weighted prevalence of toxoplasmosis in blood donors was determined to be 33\% (95\% CI, 28\%-39\%) (Foroutan-Rad et al., 2016). There are previous fragmentary seroprevalence studies in Latvia, mainly in pregnant woman, which do not show toxoplasmosis seroprevalence in Latvian population.

Given the gaps in knowledge of $T$. gondii prevalence in the Latvia, uncertainties and comorbid conditions, the aim of the present study was to determine the seroprevalence of anti-T. gondii $\mathrm{IgG}$ and $\mathrm{IgM}$ antibodies using a large set of diagnostic laboratory data collected over a period of 14 years.

\section{MATERIALS AND METHODS}

For the present study data from the largest clinical laboratory in Latvia were used. All unique patients, who were tested for presence of specific anti-T. gondii $\mathrm{IgG}$ and/or IgM antibodies with appropriate serological screening methods like enzyme-linked immunosorbent assay in the period from from 1 January 2004 to 31 December 2017, were included in the study. Use of this data to characterise epidemiology of infectious disease presents a unique opportunity to assess prevalence of infection with minimal cost, while allowing for characterisation of occurrence across time. Additionally, this approach facilitates identification of patterns of infection with respect to patient age, gender, and common comorbidities. The study was approved by the Institute of Food Safety, Animal Health and Environment "BIOR" Ethical committee.

All unique patients were evaluated for the presence of specific anti-T. gondii $\operatorname{IgG} / \operatorname{IgM}$ antibodies at first diagnosis, age, gender and comorbidity were recorded. The patient age was divided into six groups as suggested by the European Centre for Disease Prevention and Control: 0 - younger than one year; 1 - 1-6 years, 2 - 7-14 years, 3 - 15-24 years, $4-25-44$ years, $5-45-64$ years, 6 - older than 65 years. Comorbidity diagnoses were divided by disease code into 23 groups (Anonymous, 2018b). The confidence intervals (CI) of the prevalence estimates and the two-tailed $p$ values of the two-by-two table comparisons were calculated using the Mid-P Exact in open source software OpenEpi v.2.3.1 (Dean et al., 2015). Spearman`s rank-order correlation calculations for $T$. gondii seroprevalence and patients age group were performed with SPSS Statistics Version 21 (IBM Corporation, Chicago, Illinois). $p<0.05$ was considered statistically significant. 
PREVALENCE OF ANTI-TOXOPLASMA GONDII IGG AND IGM ANTIBODIES, MIN-MAX AND MEAN AGE OF PATIENTS

\begin{tabular}{l|c|c|c|c|c}
\hline & No. of tested & No. of positive & Prevalence, $\%$ & $\begin{array}{c}\text { 95\% Confidence } \\
\text { Interval }\end{array}$ & $\begin{array}{c}\text { Mean age } \\
\text { of patient } \pm \text { SD }\end{array}$ \\
\hline Anti- $T$. gondii IgG antibodies & 20428 & 7411 & 36.3 & $35.6-37.0$ & $33.7 \pm 12.2$ \\
Anti- $T$. gondii IgM antibodies & 19349 & 470 & 2.4 & $2.2-2.7$ & $30.5 \pm 11.1$
\end{tabular}

\section{RESULTS}

In total, 25069 unique patients were included in the present study. From those, $18.5 \%(\mathrm{n}=4641)$ were tested for presence of anti-T. gondii IgM antibodies, $22.8 \%(\mathrm{n}=5720)$ were tested for presence of anti-T. gondii IgG antibodies and $58.7 \%(n=14708)$ were tested for presence of anti- $T$. gondii $\operatorname{IgG}$ and $\operatorname{IgM}$ antibodies. Patients ranged in age from 0 to 86 years $($ mean $=30.3$, median $=30.0)$, and $82.1 \%(n=$ 20 586) were females and $17.9 \%(\mathrm{n}=4483)$ were males. The overall anti-T. gondii IgG prevalence (36.3\%) and was significantly $(p<0.01)$ higher than IgM prevalence $(2.4 \%)$ (Table 1).

During the studied time period, a slight decrease of anti- $T$. gondii $\mathrm{IgG}$ prevalence was observed, but it remained stable (Table 2). However, there was a significant decrease $(p<$ 0.01 ) of specific anti-T. gondii IgM prevalence during the study period (Table 2). A significant difference were observed in seroprevalence by sex; females had $1.149(95 \%$ CI 1.061-1.244) times higher risk of being specific anti- $T$. gondii $\operatorname{IgG}$ positive than males, while there was no significant difference of specific anti-T. gondii $\operatorname{IgM}$ prevalence by sex (Table 3).

In the analysis of seroprevalence by age groups, the age group under one year was excluded from further analyses as positive IgG antibody findings (23.3\%; 95\% CI 19.6-27.4) in this group were assumed to be maternal antibodies. None of the samples were positive for IgM antibodies in the age group under age of one year. A significant positive correlation $(\mathrm{r}=0.99 ; p<0.01)$ was observed between age group and anti-T. gondii $\operatorname{IgG}$ antibody prevalence, which ranged from $4.2 \%(95 \%$ CI 2.9-6.0) in patients from one to six years to $66.7 \%$ (95\% CI 61.4-71.6) in patients older than 65 years (Fig. 1A). There were no significant difference of anti- $T$. gondii $\operatorname{IgM}$ antibody prevalence by age group, however results shows that higher risk for first toxoplasmosis infection is until age of 24 years (Fig. 1B).

There was no significant difference of seroprevalence of anti-T. gondii IgG antibodies by sex in age groups, except in the fourth age group where females were observed to have significantly higher seroprevalence and 1.4 (95\% CI 1.2-1.5) times higher risk of testing specific anti- $T$. gondii IgG positive than males (Table 4).

Comorbidities to patients tested for presence of anti-T. gondii $\mathrm{IgG}$ and/or IgM antibodies in 69.9\% (95\% CI 69.2-70.7) of cases were classified as factors affecting health status or suggesting past contact with health services, which includes also monitoring of normal pregnancy. Another 4.6 (95\% CI
Table 2

PREVALENCE OF SPECIFIC ANTI-TOXOPLASMA GONDII ANTIBODIES IN THE STUDY PERIOD FROM 2004 TO 2017 IN THE LATVIAN POPULATION

\begin{tabular}{c|c|c|c|c|c|c}
\hline \multirow{2}{*}{ Year } & \multicolumn{2}{|c|}{ Anti-T. gondii IgG antibodies } & \multicolumn{3}{c}{ Anti-T. gondii IgM antibodies } \\
\cline { 2 - 7 } & $\begin{array}{c}\text { No. of } \\
\text { tested }\end{array}$ & $\begin{array}{c}\text { Preva- } \\
\text { lence }\end{array}$ & $95 \%$ CI & $\begin{array}{c}\text { No. of } \\
\text { tested }\end{array}$ & $\begin{array}{c}\text { Preva- } \\
\text { lence }\end{array}$ & $95 \%$ CI \\
\hline 2004 & 729 & 38.6 & $35.1-42.1$ & 613 & 8.8 & $6.8-11.3$ \\
2005 & 814 & 40.9 & $37.6-44.3$ & 719 & 6.4 & $4.8-8.4$ \\
2006 & 1191 & 40.2 & $37.5-43.0$ & 1040 & 3.1 & $2.2-4.3$ \\
2007 & 1347 & 39.0 & $36.4-41.6$ & 1297 & 4.5 & $3.5-5.7$ \\
2008 & 1667 & 39.7 & $37.3-42.0$ & 1698 & 3.3 & $2.5-4.3$ \\
2009 & 1574 & 26.8 & $24.9-28.7$ & 1744 & 2.2 & $1.6-3.1$ \\
2010 & 1249 & 35.7 & $33.1-38.4$ & 1404 & 1.8 & $1.2-2.6$ \\
2011 & 1441 & 35.4 & $33.0-37.9$ & 1353 & 1.5 & $0.9-2.3$ \\
2012 & 1680 & 36.5 & $34.2-38.8$ & 1483 & 1.9 & $1.3-2.7$ \\
2013 & 1565 & 34.9 & $32.6-37.3$ & 1452 & 1.6 & $1.0-2.4$ \\
2014 & 1599 & 34.5 & $32.2-36.9$ & 1546 & 1.5 & $1.0-2.2$ \\
2015 & 1727 & 34.0 & $31.8-36.3$ & 1675 & 1.2 & $0.8-1.8$ \\
2016 & 1729 & 32.4 & $30.2-34.6$ & 1512 & 1.7 & $1.1-2.4$ \\
2017 & 2116 & 35.1 & $33.1-37.2$ & 1813 & 1.2 & $0.7-1.8$ \\
Total & 20428 & 36.3 & $35.6-37.0$ & 19349 & 2.4 & $2.2-2.7$ \\
& & & & & &
\end{tabular}

Table 3

PREVALENCE OF ANTI-TOXOPLASMA GONDII ANTIBODIES BY GENDER IN LATVIA FROM 2004 TO 2017

\begin{tabular}{|c|c|c|c|c|c|c|}
\hline \multirow[t]{2}{*}{ Gender } & \multicolumn{3}{|c|}{ Anti-T. gondii $\operatorname{IgG}$ antibodies } & \multicolumn{3}{|c|}{ Anti- $T$. gondii $\operatorname{IgM}$ antibodies } \\
\hline & $\begin{array}{l}\text { No. of } \\
\text { tested }\end{array}$ & $\begin{array}{c}\text { Preva- } \\
\text { lence }\end{array}$ & $95 \% \mathrm{CI}$ & $\begin{array}{l}\text { No. of } \\
\text { tested }\end{array}$ & $\begin{array}{c}\text { Preva- } \\
\text { lence }\end{array}$ & $95 \% \mathrm{CI}$ \\
\hline Female & 17235 & 36.8 & $36.1-37.5$ & 15838 & 2.5 & $2.2-2.7$ \\
\hline Male & 3193 & 33.6 & $32.0-35.3$ & 3511 & 2.3 & $1.9-2.9$ \\
\hline
\end{tabular}

4.3-5.0) cases were classified as pregnancy, childbirth or the puerperium and $3.4 \%$ (95\% CI 3.1-3.6) cases were classified as diseases of the genitourinary system. However, cases from other classification ranged from $0.0 \%$ to $2.8 \%$.

\section{DISCUSSION}

Use of the large database presented an opportunity to assess prevalence of medical diagnosis of toxoplasmosis in the Latvian population, confirmed some trends highlighted in earlier literature, and yielded some unexpected results. Within the present study we found evidence of high exposure $(36.3 \%)$ to $T$. gondii, which is a zoonotic parasite presenting a threat to human health and life quality, food 



Fig. 1. Prevalence of specific anti-Toxoplasma gondii seroprevalence by age groups in Latvia from 2004 to 2017. A, IgG antibodies; B, IgM antibodies. Age groups: 1, 1-6 years, 2, 7-14 years, 3, 15-24 years, 4, 25-44 years, 5, 45-64 years, 6 , older than 65 years.

Table 4

PREVALENCE OF FIRST DIAGNOSIS OF ANTI-TOXOPLASMA GONDII IGG ANTIBODIES BY AGE AND GENDER AND ODDS RATIO ESTIMATES IN LATVIA FROM 2004 TO 2017

\begin{tabular}{c|ccc|c|c|c|c|c|c|c|c}
\hline \multirow{2}{*}{$\begin{array}{c}\text { Age } \\
\text { group }\end{array}$} & \multicolumn{4}{|c|}{ Anti-T. gondii IgG prevalence in females } & \multicolumn{3}{c|}{ Anti-T. gondii IgG prevalence in males } & \multicolumn{2}{c}{ Odds ratio estimates } \\
\cline { 2 - 12 } & No of tested & No of positive & $\%$ & $95 \%$ CI & No of tested & No of positive & $\%$ & $95 \%$ CI & $p$ & OR (95\% CI) \\
\hline 1 & 353 & 13 & 3.7 & $2.1-6.3$ & 461 & 16 & 3.5 & $2.1-5.6$ & $0.02 *$ & $1.1(0.5-2.2)$ \\
2 & 358 & 35 & 9.8 & $7.1-13.3$ & 368 & 28 & 7.6 & $5.3-10.8$ & 0.15 & $1.3(0.8-2.2)$ \\
3 & 2827 & 756 & 26.7 & $25.1-28.4$ & 509 & 126 & 24.8 & $21.2-28.7$ & 0.17 & $1.1(0.1-1.4)$ \\
4 & 15072 & 4690 & 31.1 & $30.4-31.7$ & 2124 & 531 & 25.0 & $23.2-26.9$ & $.01 *$ & $1.4(1.2-1.5)$ \\
5 & 1411 & 642 & 45.5 & $43.0-48.1$ & 573 & 238 & 41.5 & $37.6-45.6$ & 0.05 & $1.2(1.0-1.4)$ \\
6 & 266 & 147 & 55.3 & $49.3-61.1$ & 128 & 73 & 57.0 & $48.4-65.3$ & 0.3 & $0.9(0.6-1.4)$
\end{tabular}

Age groups: 1, 1-6 years, 2, 7-14 years, 3, 15-24 years, 4, 25-44 years, 5, 45-64 years, 6, older than 65 years.

safety, the economy and the environment (Bouwknegt et al., 2018; Anonymous, 2014; Torgerson, 2013).

The observed seroprevalence in the present study was comparable to that observed in the Netherlands (40.5\%), Italy (42\%), Germany (49.1\%), Estonia (55.8\%), and Belgium (up to 67\%) (Kortbeek et al., 2004; Pappas et al., 2009; Lassesn et al. 2016; Wilking et al. 2016). During the last decades, T. gondii seroprevalence in general has decreased (Kortbeek et al., 2004; Nowakowska et al., 2006; Dubey 2010). This tendency was observed in a study from the Netherlands where overall seroprevalence decreased from $40.5 \%$ in $1995 / 1996$ to $26.0 \%$ in $2006 / 2007$ and France, where seroprevalence decreased from $64.5 \%$ in 1997 to $54.7 \%$ in 2013 (Hofhuis et al., 2011; Guigue et al., 2018). However, there was no temporal trend of anti-T. gondii IgG prevalence in the present study and it remained stable ranging from $32.4 \%$ to $40.9 \%$, while there was a significant decrease of anti-T. gondii IgM prevalence from $8.8 \%$ to $1.1 \%$ during the study period from 2004 to 2017 . The decreasing trend might be related to significant improvement in social economic condition, which includes consuming filtered water, good quality meat and improvement in hygienic condition in general (Tenter et al., 2000).
Toxoplasma gondii seroprevalence typically increases with age, indicating acquired infection. In the present study the observed specific anti-T. gondii IgG seroprevalence increased from $4.2 \%$ in children from one to six years and reached $66.7 \%$ in patients under 65 years. Some studies suggest that the main risk factors for acquired toxoplasmosis among humans in different age groups and regions are eating undercooked lamb, beef or game, consumption of unwashed vegetables, contact with soil and travel outside Europe (Cook et al., 2000; Ertug et al., 2005; RobertGangneux and Dardé, 2012; Wilking et al., 2016). There are controversial results on close contact with cats as a risk factor, as some show that close contact with cats has no risk while others shows that it is positively associated with seropositivity (Cook et al., 2000; Wilking et al., 2016). The high $T$. gondii seroprevalence in children $(37.5 \%$, age 14-18 years) suggests that the infection pressure is substantial (Lassen et al. 2016). In Russia, the T. gondii seroprevalence observed in children from six to 12 years of age was $13.4 \%$ which is close to that observed in present study (10.2\%) (Janse et al., 2014).

A significant interaction was noted between age and gender $(p=0.023)$ in a representative, cross-sectional, serological 
study in Germany, since higher seroprevalence was observed among younger males and older females. Although not associated in univariable analysis, multivariate analysis showed that men have a 1.76-times higher chance of being seropositive (Wilking et al., 2016). In a similar study in Unites States, more females than males were identified with toxoplasmosis, respectively, $59 \%$ vs $41 \%$ of the total number of cases. The number of male to female cases was most similar at early age, became increasingly different with age, toward increased incidence in females (Lykins et al., 2016). These results correspond to those observed in the present study where no difference in seroprevalence by age and gender was observed, except at age from 25 to 44 years when females had significantly higher seroprevalence than in males. This might be explained by screening of women of reproductive age, or could potentially indicate a difference in risk of exposure to the pathogen (Lykins et al., 2016). Indeed, the present study identified almost $70 \%$ of patient as cases classified as factors influencing health status or suggesting past contact with health services, which includes also monitoring of normal pregnancy. The mean age of $T$. gondii-infected patients was 33.7 years. The mean age identifies the age when humans become infected for the first time. The high seroprevalence observed in males can be explained by use of twice as much meat and meat products in the diet than for females (Bremer et al., 2005). The seroprevalence observed in females can be explained by reproduction and by socio-economic status, and cat holding (Lykins et al., 2016, Wilking et al., 2016). High T. gondii seroprevalence in domestic cats in Latvia indicates that the environment has been contaminated with oocysts, which is supported by results on $T$. gondii prevalence in other wild and domestic animals in Latvia (Deksne and Kirjušina, 2013; Deksne et al., 2013; Deksne et al., 2017).

The present study showed that $2.4 \%$ of all tested patients had acute acquired infection of $T$. gondii. However, the present study does not provide information on whether these patients were symptomatic or asymptomatic. In previous studies, a part of the patient population (9-27\%) has been found to exhibit a persistent IgM antibody response that remains for two years or more (Gras et al., 2004).

Prevalence of comorbidities associated with toxoplasmosis was also assessed; offering insight into how commonly individuals with this infection suffer from other conditions. The present study shows that factors influencing health status or past contact with health services which includes also monitoring of normal pregnancy, pregnancy, childbirth or the puerperium and diseases of the genitourinary system, were the most prevalent disease classifications. However, the present study do not provide data to understand these relationships directionality and causality with toxoplasmosis. Previous studies showed that, compared to controls matched for age, geography, and health, patients with classifications for toxoplasmosis had greater odds of suffering from conditions including HIV, benign and malignant brain neoplasm, epilepsy, autoimmune diseases including lupus and multiple sclerosis, and psychiatric conditions including substance abuse, anxiety, bipolar disorder, and schizophrenia (Lykins et al., 2016).

These results provide baseline data showing high and stable T. gondii seroprevalence in the Latvian population. This calls for greater awareness of zoonotic parasite infection in Latvia. Antibodies against $T$. gondii appear to be formed already in childhood, indicating considerable infection pressure. In further studies to evaluate toxoplasmosis risk factors and their influence on prevalence in different age groups, gender and other significant factors, a questionnaire together with blood sample testing should be incorporated to obtain more precise information about patient lifestyles and comorbid diseases.

\section{ACKNOWLEDGEMENTS}

The authors would like to thank Sandra Dimante from the clinical laboratory for sharing the dataset from laboratory routine clinical testing.

This study was partly funded by the European Regional Development Fund "1.1.1.2. "Post-doctoral research aid" project "One Health multidisciplinary approaches for epidemiology and prevention of selected parasitic zoonosis (OMEPPAZ)” (1.1.1.2/VIAA/1/16/204).

\section{REFERENCES}

Anonymous (2014). Multicriteria-based ranking for risk management of food-borne parasites. Report of a Joint FAO/WHO Expert Meeting, 3-7 September 2012, FAO Headquarters, Rome, Italy. Food and Agriculture Organization of the United Nations/World Health Organization. 287 pp.

Anonymous (2016). Annual Epidemiological Report 2016 - Toxoplasmosis. European Centre for Disease Prevention and Control. Available at: https://ecdc.europa.eu/en/publications-data/congenital-toxoplasmosis-annual-epidemiological-report-2016-2014-data\#no-link (accessed 27.10.2018).

Anonymous (2018a). Epidemiology bulletins of Infectious diseases [Epidemiologiijas bileteni]. The Centre for Disease Control and Prevention of Latvia (in Latvian). Available from:

https://www.spkc.gov.lv/lv/statistika-un-petijumi/infekcijas-slimibas/epid emiologijas-bileteni1 (accessed at 25.10.2018).

Anonymous (2018b). International Classification of Diseases 11. World Health organization. Available from: https://icd.who.int (accessed at 25.10.2018).

Berger, F., Goulet, V., Le Strat, Y., Desenclos, J. C. (2009). Toxoplasmosis among pregnant women in France: Risk factors and change of prevalence between 1995 and 2003. Revue d'epidemiologie et de sante publique, 57, 241-248.

Bessieres, M. H., Roques, C., Berrebi, A., Barre, V., Cazaux, M., Seguela, J. P. (1992). IgA antibody response during acquired and congenital toxoplasmosis. J. Clin. Pathol., 45, 605-608.

Bouwknegt, M., Devleesschauwer, B., Graham, H., Robertson, L. J., van der Giessen, J. W. (2018). Prioritisation of food-borne parasites in Europe, 2016. Eurosurveillance, 23, 9.

Bremer, V., Bocter, N., Rehmet, S., Klein, G., Breuer, T., Ammon, A. (2005). Consumption, knowledge, and handling of raw meat: A representative cross-sectional survey in Germany, March 2001. J. Food Prot., 68, 785-789.

Cook, A. J. C., Holliman, R., Gilbert, R. E., Buffolano, W., Zufferey, J., Petersen, E., Jenum, P. A., Foulon, W., Semprini, A. E., Dunn, D. T. 
(2000). Sources of toxoplasma infection in pregnant women: European multicentre case-control study. Commentary: Congenital toxoplasmosis further thought for food. Brit. Med. J., 321, 142-147.

Dean, A. G., Sullivan, K. M., Soe, M. M. (2015). OpenEpi: Open Source Epidemiologic Statistics for Public Health. Available at: http://www.openepi.com (accessed 27.10.2018).

Deksne, G., Kirjušina, M. (2013). Seroprevalence of Toxoplasma gondii in domestic pigs (Sus scrofa domestica) and wild boars (Sus scrofa) in Latvia. J. Parasitol., 99, 44-47.

Deksne, G., Ligere, B., Šneidere, A., Jokelainen, P. (2017). Seroprevalence and factors associated with Toxoplasma gondii infections in sheep in Latvia: Latvian dark headed sheep breed associated with higher seroprevalence. Vector Borne Zoonotic Dis., 17, 478-482.

Deksne, G., Petrusēviča, A., Kirjušina, M. (2013). Seroprevalence and factors associated with Toxoplasma gondii infection in domestic cats from urban areas in Latvia. J. Parasitol., 99, 48-50.

Dubey, J. P. (2010). Toxoplasmosis of Animals and Humans. 2nd edition. CRC Press, Maryland. 336 pp.

Ertug, S., Okyay, P., Turkmen, M., Yuksel, H. (2005). Seroprevalence and risk factors for toxoplasma infection among pregnant women in Aydin province, Turkey. BMC Publ. Health, 5, 66

Foroutan-Rad, M., Majidiani, H., Dalvand, S., Daryani, A., Kooti, W., Saki, J., Hedayati-Rad, F., Ahmadpour, E. (2016). Toxoplasmosis in blood donors: A systematic review and meta-analysis. Transfus Med Rev., 30, 116-122.

Gras, L., Gilbert, R. E., Wallon, M., Peyron, F., Cortina-Borja, M. (2004). Duration of the IgM response in women acquiring Toxoplasma gondii during pregnancy: Implications for clinical practice and cross-sectional incidence studies. Epidemiol. Infect., 132, 541-548.

Guigue, N., Léon, L., Hamane, S., Gits-Muselli, M., Le Strat, Y., Alanio, A., Bretagne, S. (2018). Continuous decline of Toxoplasma gondii seroprevalence in hospital: A 1997-2014 longitudinal study in Paris, France. Front. Microbiol., 9, 2369.

Hofhuis, A., van Pelt, W., van Duynhoven, Y. T., Nijhuis, C. D., Mollema, L., van der Klis, F. R., Havelaar, A. H., Kortbeek, L. M. (2011). Decreased prevalence and age-specific risk factors for Toxoplasma gondii IgG antibodies in The Netherlands between 1995/1996 and 2006/2007. Epidemiol. Infect., 139, 530-538.

Received 1 November 2018

Accepted in the final form 20 February 2019
Janse, J. J., Wong, G. W., Potts, J., Ogorodova, L. M., Fedorova, O. S., Mahesh, P. A., Sakellariou, A., Papadopoulos, N. G., Knulst, A. C., Versteeg, S. A., Kroes, A. C. M. Vossen, A. C. T. M., Ponce, M. C., Kummeling, I., van Ree, P. B.R., Yazdanbakhsh, M. (2014). The association between foodborne and orofecal pathogens and allergic sensitisation EuroPrevall study. Pediatr. Allergy Immunol., 25, 250-256.

Kortbeek, L. M., De Melker, H. E., Veldhuijzen, I. K., Conyn-Van Spaendonck, M. A. E. (2004). Population-based Toxoplasma seroprevalence study in The Netherlands. Epidemiol. Infect., 132, 839-845.

Lassen, B., Janson, M., Viltrop, A., Neare, K., Hütt, P., Golovljova, I., Tummeleht, L., Jokelainen, P. (2016). Serological evidence of exposure to globally relevant zoonotic parasites in the Estonian population. PloS One, 11, e0164142.

Luft, B. J., Remington, J. S. (1992). Toxoplasmic encephalitis in AIDS. Clin. Infect. Dis., 15, 211-222.

Lykins, J., Wang, K., Wheeler, K., Clouser, F., Dixon, A., El Bissati, K., Zhou, Y., Lyttle, C., Rzhetsky, A., McLeod, R. (2016). Understanding toxoplasmosis in the United States through "Large Data" Analyses. Clin. Infect. Dis., 63, 468-475.

Nowakowska, D., Stray-Pedersen, B., Śpiewak, E., Sobala, W., Małafiej, E., Wilczyński, J. (2006). Prevalence and estimated incidence of Toxoplasma infection among pregnant women in Poland: A decreasing trend in the younger population. Clin. Microbiol. Infect., 12, 913-917.

Pappas, G., Roussos, N., Falagas, M. E. (2009). Toxoplasmosis snapshots: Global status of Toxoplasma gondii seroprevalence and implications for pregnancy and congenital toxoplasmosis. Int. J. Parasitol., 39, 1385-1394.

Robert-Gangneux, F., Dardé, M. L. (2012). Epidemiology of and diagnostic strategies for toxoplasmosis. Clin. Microbiol. Rev., 25, 264-296.

Sonar, S. S., Brahmbhatt, M. N. (2010). Toxoplasmosis: An important protozoan zoonosis. Vet. World, 3, 436.

Tenter, A. M., Heckeroth, A. R., Weiss, L. M. (2000). Toxoplasma gondii: From animals to humans. Int. J. Parasit., 30, 1217-1258.

Torgerson, P. R. (2013). One world health: Socioeconomic burden and parasitic disease control priorities. Vet. Parasitol., 195, 223-232.

Wilking, H., Thamm, M., Stark, K., Aebischer, T., Seeber, F. (2016). Prevalence, incidence estimations, and risk factors of Toxoplasma gondii infection in Germany: A representative, cross-sectional, serological study. Sci. Rep., 6, 22551

\section{RETROSPEKTĪVI SEROLOGISKIE PIERĀDĪJUMI PAR PASAULĒ NOZĪMĪGA ZOONITISKĀ PARAZĪTA TOXOPLASMA GONDII BIEŽO SASTOPAMĪBU LATYVIJAS IEDZ̄̄VOTĀJU POPULĀCIJĀ}

Toksoplazmoze ir nozīmīga infekcija, ko ierosina vienšūnas parazìts Toxoplasma gondii, zoonotisks parazīts, kas ierosina plaša spektra cilvēku un dzīvnieku saslimšanas, galvenokārt saistītas ar centrālo nervu sistēmu. Cilvēks var iegūt toksoplazmozi, uznemot neapstrādātu vai nepietiekami apstrādātu gaḷu, kas satur T. gondii audu cistas, uzṇemot oocistus ar kontaminētu pārtiku vai ūdeni, ko izplata invadētie kaķi, un vertikāli pārnesot auglim caur placentu no mātes grūtniecības laikā. Šì pētījuma mērkis bija novērot specifisko pret $T$. gondii IgG un IgM antivielu seroprevalenci, izmantojot plašu klīniskās diagnostikas laboratorijas datu kopu 14 gadu periodā. Kopumā šajā pētījumā tika iekḷauti 25069 pacienti. Kopējā specifisko pret-T. gondii IgG antivielu prevalence tika novērota 36,3\% un bija būtiski $(p<0,01)$ augstāka nekā IgM antivielu prevalence, kas bija 2,4\%. IgG antivielu pozitīvo pacientu vidējais vecums bija 33,7 $\pm 12,2$ gadi. Būtiska pozitīva korelācija $(\mathrm{r}=0,99 ; p<0,01)$ tika novērota starp pacientu vecuma grupām un pret- $T$. gondii IgG antivielu prevalenci, un tā svārstījās attiecīgi no 4,2\% līdz 66,7\%. Visbiežākās (69,9\%; 95\% CI 69,2-70,7) blakus diagnozes pacientiem, kam tika veikti izmeklējumi, lai noteiktu pret-T. gondii IgG un IgM antivielu klātbūtni, tika klasificētas kā faktori, kas ietekmē veselības stāvokli, tostarp arī normālas grūtniecības uzraudzību. 